\title{
The Theoretical Analysis of the Impact of RMB Exchange Rate Movement on CHINA'S Textile Export
}

\author{
Ma Xiaohong \\ College of Economics, Tianjin Polytechnic University, Tianjin, 300072, China \\ email: 153665789@qq.com
}

Keywords: RMB's Exchange Rates; Textile Export; Analysis

\begin{abstract}
This paper introduces relevant theory of exchange rate, discusses the history of China's exchange rate reform, analyzes the background factors of the RMB appreciation, and Introduces the movement in RMB exchange. Finally, this paper demonstrates the huge impact of RMB appreciation on China's textile and garment exports industry analysis.
\end{abstract}

\section{Overview}

Since reform and opening, China has begun a period of rapid economic growth, in which the foreign trade plays an important role. Especially after China joined WTO in 2001, the global market has brought a lot of opportunities to export-oriented enterprise. [1] China's export has increased in a rapid rate, and China's trade surplus with the rest of the world has hit records every year. However, the "double surplus" has raised the fear of China's development from the international communities, which therefore have implemented all kinds of ways to hinder China's export in order to protect their own economy. Among all the ways, the voice that calls for the appreciation of RMB is the most intensive, hoping to raise the cost of china's export products and weaken the competitiveness of China's goods. Therefore, under the domestic and international pressure, the reform of RMB exchange rate and thus the appreciation of RMB are unavoidable.

On July 21st, 2005, the dawn of RMB appreciation, the People's Bank of China began to implement the floating exchange rate system, under management and adjustment, on the base of the market supply and demand, and referring to a basket of currencies. RMB appreciation has caused various impacts on different industries in China. The most important thing is that RMB appreciation raises the cost of China's export products and thus impairs the international competitiveness of them.

As the pillar of China's traditional industries, textile and apparel industry played an important role in the China's economic development. Relying on the low cost and advantageous domestic and international conditions, the export of China's textile and apparel is the leading force that earns foreign exchange, balances international payments, creates jobs and stabilizes economic growth. However, RMB appreciation has brought unprecedented crisis to China's export industry, especially textile and apparel industry, which earns their living by relying on low cost.

\section{Movement in RMB Exchange Rate}

The exchange rate is the price of one currency expressed in another currency. The frequent fluctuations of a country's currency exchange rate are bound to affect a country's foreign trade carried out smoothly.

\subsection{Movement in NEER (Nominal Effective Exchange Rate) of RMB}

NEER represents the relative value of a home country's currency compared to the other major currencies being traded. Since 1994, China has implemented floating exchange rate system. As shown in the Figure 1, from 1994 to 2005, although the exchange rate system was under management, RMB exchange system is mainly based on the market principle of supply and demand. But, the NEER of RMB changes slightly, because China keeps RMB pegged against US dollar for a long time. At that time, the NEER of RMB changed little, and stabilized at about 1 US dollar 
against 8.277 Yuan. On June 21 ${ }^{\text {st }}$, 2005, China implemented the reform of RMB exchange rate, and RMB was appreciated at 1 USD against 8.11 Yuan by 2.1\%. After that, RMB exchange rate hit the record high time after time. RMB appreciated to 7.9982 Yuan against the USD on May 15, 2006, the first time that the currency fell below 8 in 12 years. But this trend did not slow down after that. In 2008, the appreciation of RMB accelerated obviously, and, on April $10^{\text {th }}$, 2008, the central parity of RMB against USD broke "7"- the record high-- at 1 USD against 6.9920 Yuan. On May $23^{\text {rd }}, 2013$, the central parity of RMB exchange rate is 1 USD against 6.1305 Yuan-a new record high since the reform of RMB exchange rate in 2005.

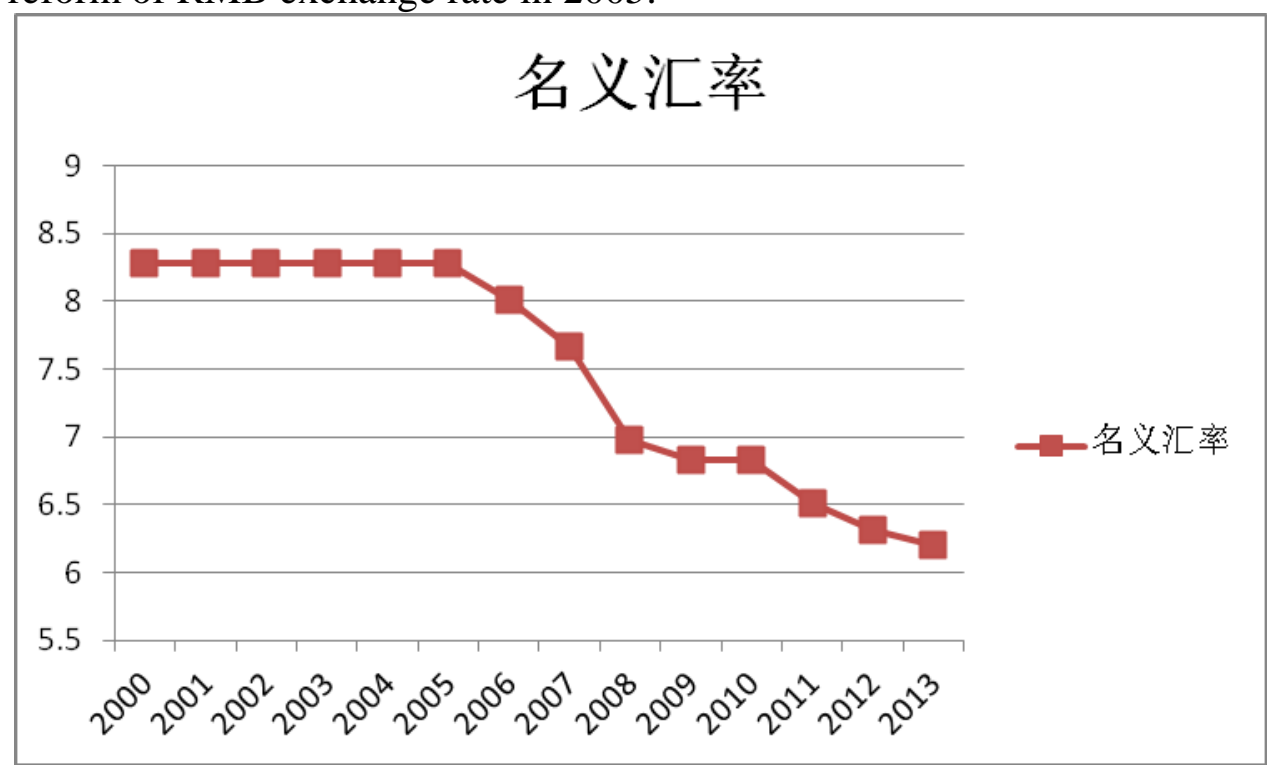

Fig 1 NEER of RMB since 2000

\subsection{Movement in REER (Real Effective Exchange Rate) of RMB}

Trade globalized all over the world, countries contact frequently with each other, and their foreign exchange increases and varies. The value of currency cannot be easily indicated by a single currency, such as the way used by NEER. Therefore, it is really necessary to use REER to reflect the comprehensive purchasing power of a country. REER (Real Effective Exchange Rate) is the weighted average of a country's currency relative to an index or basket of other major currencies adjusted for the effects of inflation. As show in the Figure 2.

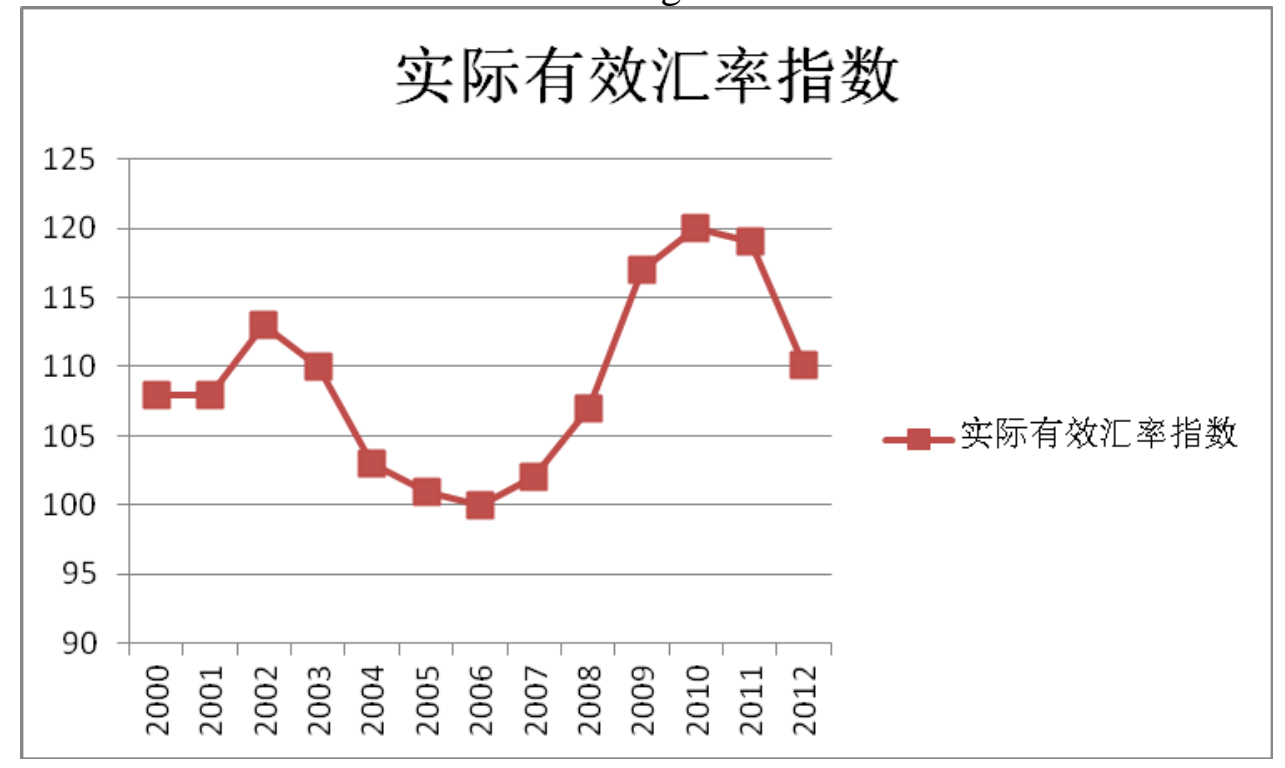

Fig 2 REER of RMB since 2000 


\section{The Negative Impact of RMB Appreciation on CHINA'S Textile Export}

Response to RMB appreciation, governments adopted different policies, which injected liquidity to the banks, but this was a contradiction with the 2001-2008 China's tightening domestic monetary policy. The U.S. dollar interest rates decreased, RMB interest rate increased. It caused RMB interest rate much higher than the U.S. dollar interest rates, resulting in a lot of hot money inflow into China, that accelerated the dollar depreciation and RMB appreciation, and thus the price advantage of Chinese exports further decrease.

\subsection{RMB appreciation makes profits declined and competition fierce}

Since reform of RMB exchange rate on July $21^{\text {st }}, 2005$, RMB goes stronger gradually. Up to 2012, RMB has appreciated about 21\% against USD. RMB appreciation results in huge loss of profits in textile export industry. Considering the above-scale textile enterprises in China, every one percent RMB appreciation against USD would result in a 5000 to 6000 million decline in the profit of textile industry. Since the subprime crisis in 2007, the profits of China's textile industry has grown significantly slowly. In 2007 when global economy was influenced deeply by the financial crisis, the profit of China's textile industry fell by $25.4 \%$, and a lot of small-scale textile enterprises went out of business in that year.

With the global economy recovered in 2010, the profit of China's textile industry has risen somewhat. Meanwhile, textile industry has indicated polarization trend-90\% of the profit in this industry was contributed by the $10 \%$ of the enterprises. With RMB appreciated gradually, China's textile exporting enterprises are confronting more and more competition from both the domestic and international pressure. [2]

In domestic market, the textile industry is mainly filled by small-scale enterprises, which account for over 95\%, because of the low entry threshold. These enterprises meet the domestic demand. On the other hand, the enterprises above designated size focus on foreign export. However, RMB appreciated, these larger enterprises began to turn to domestic market, causing the domestic market serious that was already competitive. Even worse, it contributes to vicious competition among them.

In the international market, with RMB appreciated, domestic costs of labor and raw material rise rapid, and thus export price rises correspondingly. Moreover, some countries with low cost of labor, such as Vietnam, Thai and Africa, began to own more advantage, and become our competitor in the export market.

\subsection{RMB appreciation drives foreign investment out of textile industry}

After the Reform and Opening-up, provinces along the southeast coast of China have become the major market to attract foreign investment. Foreign investors mainly focus on the low cost of the labor and raw material, and invest mostly to manufacture industry, in order to supply product by relying on the low export price. [3] But for foreign investors, RMB appreciation contributes to the increase in the cost of labor and raw materials, and thus the export price relative to global price rises eventually, causing their profits dropped rapidly. Finally, these investments turn to the regions that are more advantageous. Therefore, as we can imagine, China's textile export grow slower than it used to, and the percentage of foreign investment enterprises will drop inevitably in the future.

\subsection{RMB appreciation pushes up the cost of China's textile enterprises}

With China's economy developed rapidly in recent years, Chinese residents' living standards improve correspondingly, and it is necessary to enhance the wage level of labors. The improvement of the wage level is detrimental to labor-intensive industry such as textile industry-the cost of the 
product rises. [4] Moreover, the cost of the raw material rises up rapidly, worsening the condition of China's textile industry. Textile export is the major part of China's foreign export, and the raw material of the manufacture is mainly from import. [5] Therefore, RMB appreciation contributes to the loss of the profit in textile export, and thus causes huge challenges to the textile export enterprises. [5]

\section{Countermeasures at Macro Level and Micro Level}

\subsection{Supporting measures from domestic government}

Confronting the adverse impact of RMB appreciation on China's textile industry, governments must take effective measures so as to protect its own markets, expand the market of national exports, adjust domestic industrial structure, accumulate capital and funds and develop their own textile industry, thus reducing the negative effects of RMB appreciation.

\subsection{Supporting measures from textile and garment industry association}

Textile and garment industry association is a self-regulatory organization that creates favorable environment for enterprises, provides immediate and effective information, and standardizes norm of competition in order to guide the whole market to the right direction. [6]

\subsection{Measures to cope with exchange rate fluctuation in short term}

Because of the discontinuity and non-uniqueness of export, enterprises could make use of means of trade settlement, such as financial derivatives, to avoid exchange risk. With the development and perfection of domestic financial market, more tools will be accepted by domestic enterprises to avoid exchange risks.

\subsection{Measures to cope with exchange rate fluctuation in long term}

As one of the pillar industries for Chinese national economy, textile and apparel industry still possess great potentials to develop. However, the kept-appreciating RMB would influence and put pressure on the labor-intensive textile industrial development, so that China has to strengthen the innovation ability, develop new drives and establish new modern textile industrial development system. [7]Moreover, the industry also should enhance technological advancement, improve the laborer quality and management, and emphasize energy-saving and circular economy, aiming at promoting a sustainable healthy industrial development.

\section{Acknowledgement}

In this paper, the research was sponsored by the Philosophy and Social Science Program Foundation of Tianjin (Project No. TJLJ11-012).”

\section{References}

[1] Wang Ting. Restructuring the New Competition Advantages [J]. China Textile, 2013, 1

[2] Shang Lin'aiyi. Export 2008: Riding a Tiger- Influence of CPI Growth and RMB Appreciation on Chinese Textile Export[J]. China Textile, 2008, 3

[3] Chen Xiangli. Overview of China Textile Industry (1-11, 2012): Operation Analysis of China's Tech-textile Industry in the First Three Quarters of 2012 [J]. China Textile, 2013, 2

[4] Aiping YAO. The Impact and Mechanism Research of China's Foreign Trade by the Global Financial Crisis[J]. IPCSIT, 2011, 2nd

[5] Aiping YAO. The Impact and Mechanism Research of China's Foreign Trade by the Global Financial Crisis[J]. IPCSIT, 2012, 2nd

[6] Jiang N. Effect of Technical Barriers to Trade on Chinese Textile Product Trade[J]. International Business Research, 2009, 1(3): P91.

[7] Ma X H. Research on Impacts of International Textile Trade Development on Chinese Textile Trade and Countermeasures[J]. China-USA Business Review, 2008, 7(5): 55-59. 